\title{
The Fishing Grounds and the Exploitation Status of Kawakawa (Euthynnus affinis) in Java Sea, Indonesia
}

\author{
Siti Mardlijah*, Andina Ramadhani Putri Pane, Moh Fauzi, Helman Nur Yusuf, Heri Widiyastuti, Herlisman, Achmad \\ Zamroni, Tegoeh Noegroho, Hufiadi, Karsono Wagiyo
}

Research Institute for Marine Fisheries, Cibinong, Bogor, Indonesia

ARTICLE INFO

\section{Article history:}

Received November 28, 2021

Received in revised form December 2, 2021

Accepted December 9, 2021

\section{KEYWORDS}

exploitation,

fishing ground,

FMA 712,

Java Sea,

kawakawa

\begin{abstract}
Kawakawa (Euthynnus affinis) is one of the highly favored mackerel tunas caught in Java Sea. The increase in demand due to local consumption and export eventually increases fishing that is proportional to the exploitation status. To maintain the fish resource, a scientific study should be carried out on the fishing grounds and the exploitation status of kawakawa. This study was carried out for 3 years, i.e. in March to October 2017, June to December 2018, and February to November 2019 at Pekalongan National Fishing Port in Pekalongan, Central Java, with 9,511 fish as the study objects. The data analysis was carried out by observing the fishing grounds using GPS and through interview. In addition, the exploitation status was analyzed using FISAT II application and ELEFAN program. The fishing grounds were mostly coastal waters with $15-55 \mathrm{~cm}$ sized kawakawa. The size of the first caught (Lc) of the kawakawa in this area ranged from $26.9 \mathrm{~cm}$ to $38.4 \mathrm{~cm}$. The fish recruitment occurred all year long, peaking in Apr at $15.97 \%$ and Juli $13.62 \%$. The fish natural mortality (M) was smaller than its fishing mortality (F), while its exploitation status was 0.66 (overfished), meaning that the current fishing efforts should be reduced by $32 \%$. The other management efforts that can be carried out are among others conservation, keeping the fishing grounds outside the spawning grounds, and controlling the mesh size.
\end{abstract}

\section{Introduction}

Tuna, skipjack, and mackerel tuna are economically important for fisheries and they are export commodities. Ahmed et al. (2015) stated that tuna fishing is dominant in Japan, Taiwan, Indonesia, South Korea. Indonesia produced the three species from various sea, such as the Indian Ocean, Java Sea, Lombok, Sunda Strait, Malacca Strait, and others. Based on the data, 1,240,089 tons of three species were exported in 2012, it increased to $1,273,227$ tons in 2014, and it declined to $1,126,079$ tons in 2018 (KKP 2018).

Mackerel tuna is favored by people because the price is not too high and it has nutritional value. Its fat content is only $0.87 \%$, compared to largehead hairtail and spanish mackerel (Pratama et al. 2011). The production of mackerel tuna in Indonesia increased by $2.02 \%$, i.e. from 432,138 tons (in 2012 ) to 471,009 tons (in 2017) (KKP 2018). This increase was in line

\footnotetext{
* Corresponding Author

E-mail Address: s.mardlijahbrpl@gmail.com
}

with Mujib et al. (2013) who stated that mackerel tuna is one of the main export commodities.

Mackerel tuna in Indonesia consists of several species, such as frigate tuna (A. thazard), bullet tuna (A. rochei), longtail tuna (Thunnus tonggol), and kawakawa (E. affinis), as well as other tuna and skipjack tuna species. According to the Decree of the Minister of Maritime Affairs and Fisheries No. 50 Year 2017, large pelagic non-tuna fish has high potential in the Java Sea, i.e. 72,812 tons, meaning that mackerel tuna has high potential as well in this sea and is able to become a commodity the fishers can rely on in West, Central, and East Java Provinces. One of the fishing grounds for mackerel tuna is the Java Sea with several landing sites in Pekalongan, Indramayu, Tegal, and others. According to (Shabrina et al. 2017), an area of around 50 nautical miles from Karangsong, Indramayu, is one of the potential fishing grounds for mackerel tuna.

Java Sea has become a fishing ground for both traditional boats under 5 GT and above 10 GT due to its high fertility that results in numerous fish schools. The waters' fertility is affected by monsoons that 
leads to high chlorophyll supply (Gaol and Sadhotomo 2007). Malacca Strait, Java Sea, and Arafura Sea are the locations with the highest average of water fertility, compared to the other areas in Indonesia, particularly the coastal areas to the east of Lampung and to the south of Kalimantan (Realino et al. 2007). Fertile waters accumulate planktons, food sources for fish. In addition, (Wujdi and Suwarso 2014) stated that planktons are the determining factor for the production and the abundance of fish resources.

Mackerel tuna mostly caught in Java Sea is of several species, i.e. frigate tuna, bullet tuna, longtail tuna, and kawakawa. The kawakawa (E. affinis) is one of the most landed fish in Pekalongan National Fishing Port. The fish has unique characteristics, i.e. oblique, curved black stripes above the ribs and black spots between fin and abdomen (Hidayat et al. 2019). It is an important commodity in fishing sector, according to Cantor in (Santos et al. 2010). In addition, the data from (IOTC 2017) showed that until December 2017, three-quarters of the kawakawa production in the world was supplied by 4 countries, i.e. Indonesia (27\%), India (23\%), Iran (18\%), and Pakistan (8\%). Mackerel tuna are mostly caught using 2 fishing gears, i.e. gillnet and purse seine for large pelagic fish. Based on the data from Satu Data KKP, the production of mackerel tuna in Central Java increased, i.e. from 9,039 tons in 2010 to $18,770.39$ in 2018, although the number decreased to $15,193.16$ tons in 2019.

Such high demand for mackerel tuna production is in line with the increase in the fishing efforts that accelerate high exploitation, as shown by the exploitation of the mackerel tuna in Java Sea (Fisheries Management Area 712) that reached 0.63\% (the Decree of the Minister of Maritime Affairs and Fisheries No. 50 Year 2017), indicating that the fish is already fully exploited. In addition, studies by Hidayat et al. (2019) and Chodrijah et al. (2013) also suggested similar results, i.e. kawakawa's length at first capture (Lc) is smaller than its size at first gonadal maturity (Lm), and kawakawa is indeed already fully exploited. This indicates that the exploitation activities should take into account precautionary principles and the fishing activities require strict supervision. According to (Mulyana et al. 2011), when exploitation is not supervised, the fishing activities will ignore the conditions of the environment and the resource itself.

Management efforts require scientific studies as the bases in making decision and monitoring the exploitation of mackerel tuna, particularly kawakawa (Euthynnus affinis). Although the biological aspects and the exploitation of kawakawa in Java Sea had been studied in the previous research, the fishing grounds based on fishermen's coordinates, the population dynamics, and the updated exploitation rate had not been determined. This research aimed to contribute to the calculation of the number of mackerel tuna stocks in general and to inform the management of kawakawa resources in Java Sea.

\section{Materials and Methods}

\subsection{Data Collection}

The data were collected in three (3) years, i.e. from March to October 2017, June to December 2018, and February to November 2019, at Pekalongan National Fishing Port in Pekalongan, Central Java. The data collection was carried out regularly by the researcher, assisted by an enumerator who collected data daily each month. The data on the locations of the fishing grounds were collected by the researcher and the enumerator by conducting interviews and checking the fishers' GPS when their boats landed. The data were then inputted into a data collection form for landing and operation. In addition, the data on the fish size were collected by measuring the fork length (FL) of the kawakawa using a measuring tape on a total of 3,665 fish (2017), 3,524 fish (2018), and 2,322 fish (2019) (Figure 1). The data were collected from the boats that landed their catch from the fishing grounds in Java Sea (FMA 712) in 2017 (Figure 2a) and in 2018 (Figure 2b) and that used gillnets and purse seine as their fishing gears.

\subsection{Data Analysis}

Based on the interview, the locations of the fishing grounds in the Java Sea were analyzed to determine the distribution of the fishing grounds. The data were then plotted on a map with 1-by-1-degree latitudelongitude grids. The fork length (FL) of the fish were tabulated monthly and analyzed to acquire the distribution of the fish size and the dominant size of the caught fish. The distribution of the caught fish was used as a basis for calculating the mean length at first capture (LC) of the fish. The analysis was carried out using a standard logistic curve and an

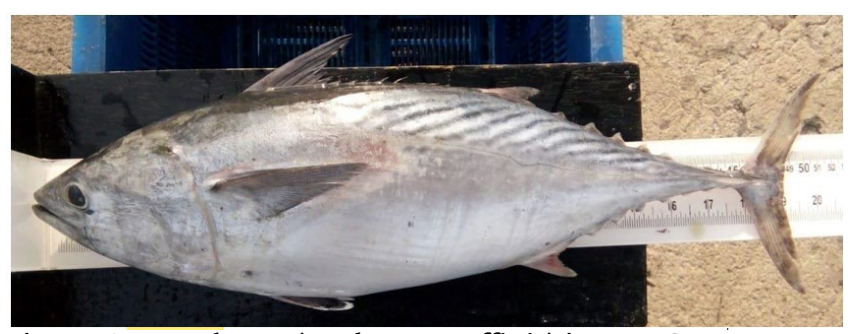

Figure 1. Kawakawa (Euthynnus affinis) in Java Sea 


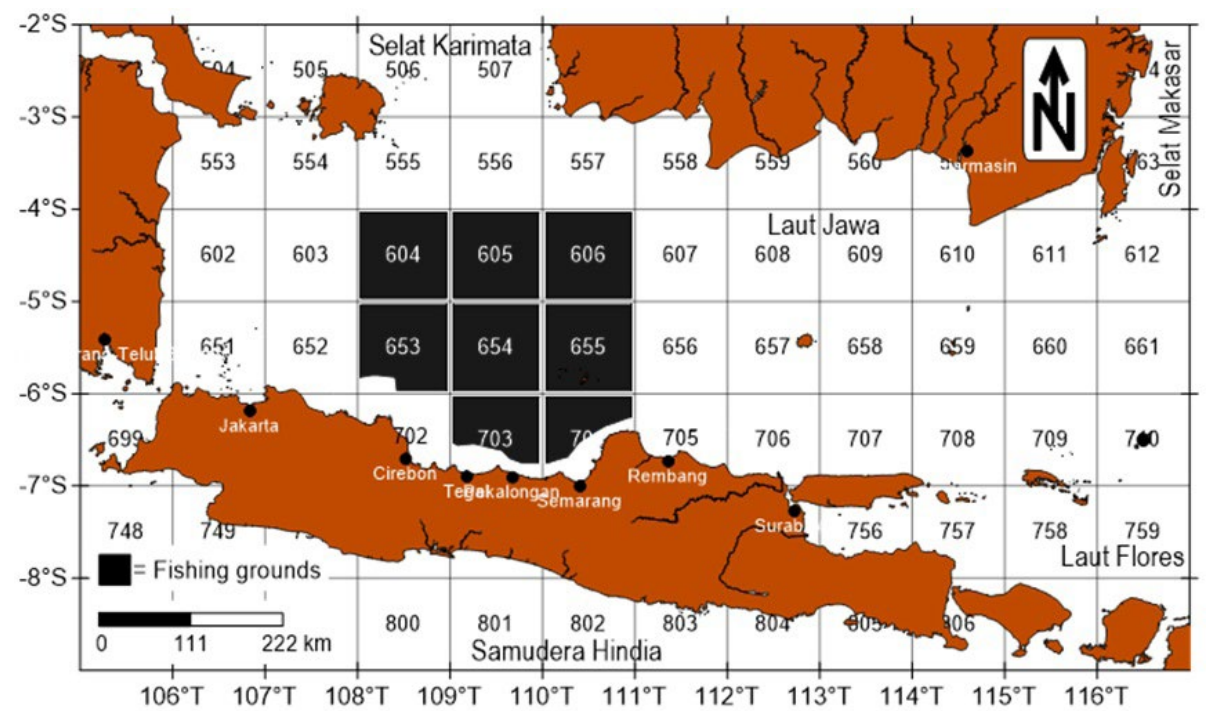

A

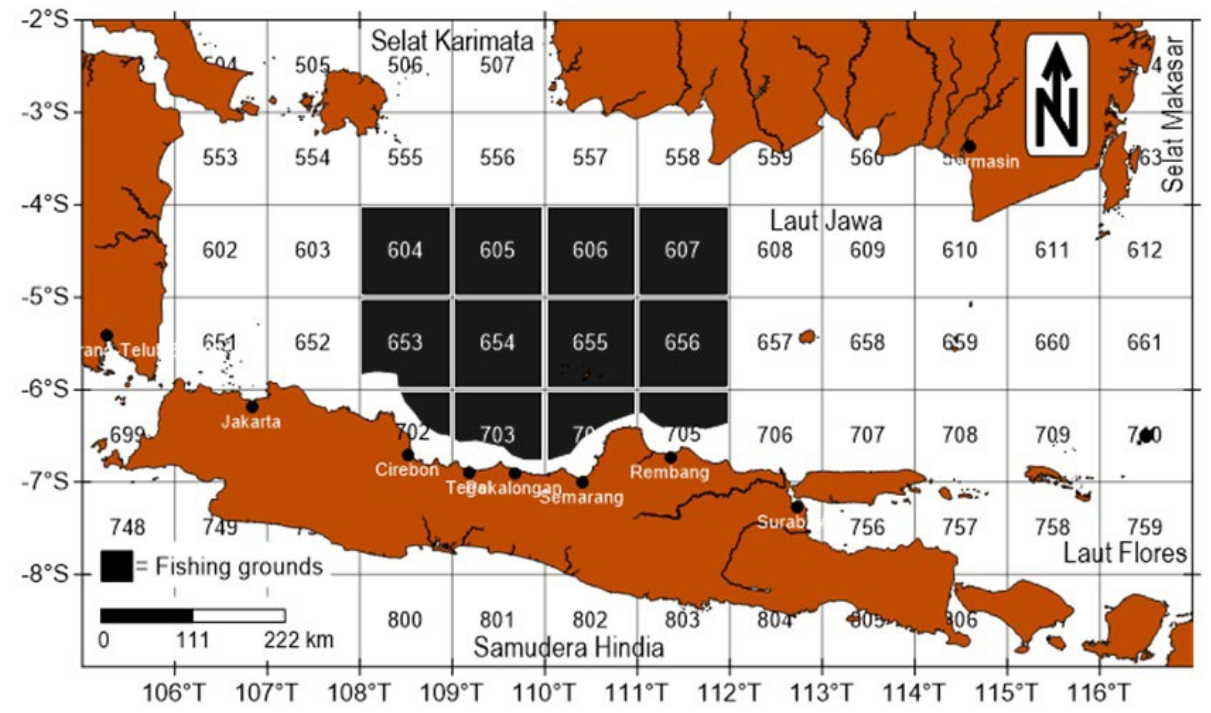

B

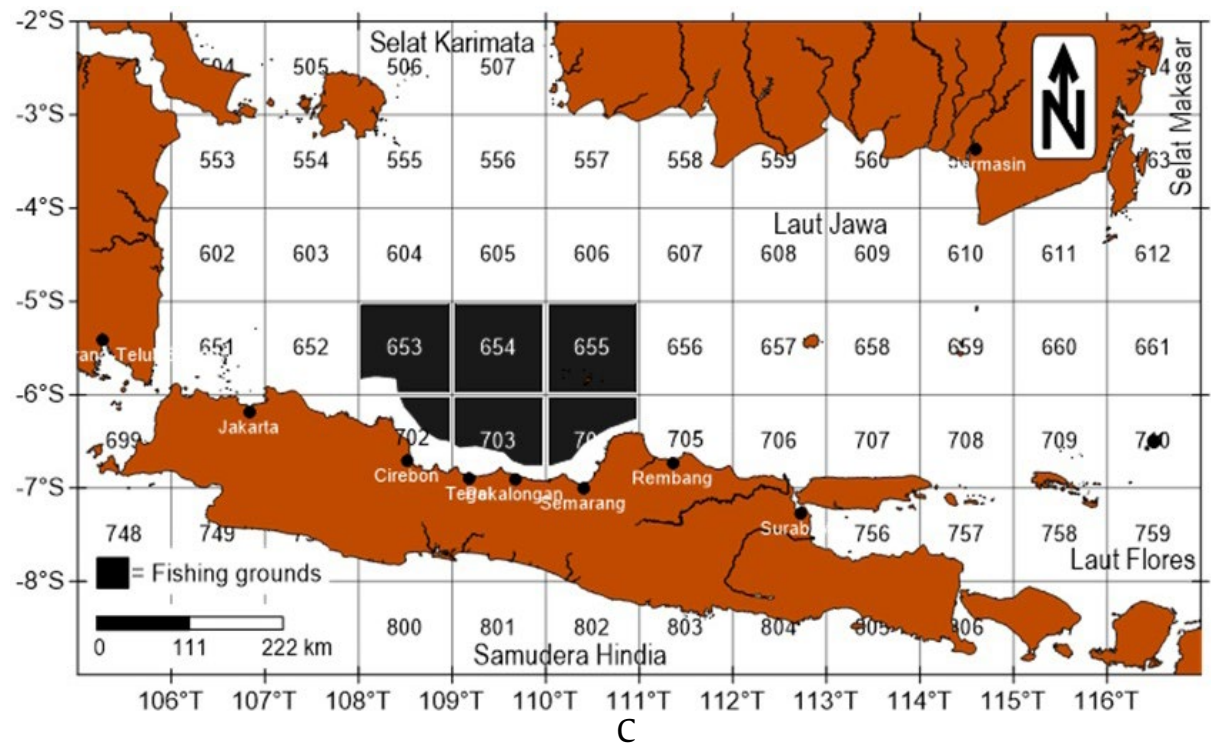

Figure 2. The fishing grounds of kawakawa (Euthynnus affinis) in Java Sea in (A) 2017, (B) 2018, and (C) 2019 
intersection point of $50 \%$ of the cumulative frequency (King 2007).

Population dynamics such as growth rate $(K)$, asymptotic length $\left(\mathrm{L}^{\infty}\right)$, natural mortality $(\mathrm{M})$, total mortality ( $\mathrm{Z}$ ), and fishing mortality ( $\mathrm{F}$ ) were analyzed to serve as the basis to determine the exploitation status (E) of the fish. The analyses were carried out using FiSAT program (FAO-ICLARM Stock Assessment Tools) (Gayanilo et al. 1996). The asymptotic length $(\mathrm{L} \infty)$ and the growth rate $(\mathrm{K})$ were estimated using ELEFAN program (Electronic Length Frequency Analysis) developed by (Pauly and David 1981) and (Gayanilo et al. 1996). In addition, the total mortality was analyzed using catch curve method that was the slope (b) between $\mathrm{Ln} N / \mathrm{t}$ and the relative age (Sparre and Venema 1999). The analysis on the estimation of the theoretical age when the fish length equals to zero was carried out using an empirical equation by (Pauly 1980) in (Sparre and Venema 1999). In addition, the fish natural mortality was analyzed using a formula by (Pauly 1980). According to (Sparre and Venema 1999), the fishing mortality (F) was acquired by subtracting natural mortality (M) from the total mortality $(M)(F=Z-M)$. Finally, the exploitation status (E) was calculated by dividing the fishing mortality $(F)$ by the total mortality $(Z)(E=$ $\mathrm{F} / \mathrm{Z}$ ).

\section{Results}

\subsection{Fishing Grounds}

In Java Sea, the fishing grounds of kawakawa were situated in Indramayu, Cirebon, Tegal, Pekalongan, until Semarang waters. Although in 2017 and 2018 the fishermen's fishing activities were carried out up to the bordering area with Kalimantan in the fishing grids No. 604, 605, 606, 607, 653, 654, 655, 656, 703, and 704, in 2019 the activities were predominantly carried out in the areas closer to the coasts (Figure $2 \mathrm{a}, \mathrm{b}$, and $\mathrm{c}$ ).

\subsection{Size Structure and the Size at First Capture}

The structure of the fork length (FL) of the kawakawa caught in Java Sea consisted of the size 19$53 \mathrm{~cm}$ (2017), 19-55 cm (2018), and 15-51 cm (2019).
The dominant size of the fish changed from 45 to 47 $\mathrm{cm}$, and the size decreased to $21 \mathrm{~cm}$ in 2019 (Figure 3 ). Such decrease in the fish size may be because of the fishing gears used or the fishing grounds.

Based on the size structure analysis, the size at first capture (Lc) of kawakawa was $37.1 \mathrm{~cm}$ (2017), $38.4 \mathrm{~cm}$ (2018), and $26.9 \mathrm{~cm}$ (2019) (Figure 4). The result of the analysis indicated that the fish caught were getting smaller (Figure 4). The Lc indicated that the fish of those sizes supposedly should not be caught because compared to the size at first gonad maturity in other marine areas, fish of such sizes were considered to have not reached their gonad maturity yet.

\subsection{Population Dynamics and Exploitation Status}

Based on the analysis of the size structure, the growth rate $(\mathrm{K})$ of kawakawa was 0.66 per year, with asymptotic length $(\mathrm{L} \infty) 59.95 \mathrm{cmFL}$ (Figures 5 and $6)$. The growth rate indicated that kawakawa grew slowly in Java Sea as the rate was $<1$.

The recruitment of kawakawa in this sea occurred all year long, i.e. in January (1.93\%), February (4.90\%), Mar (10.75\%), peaking in Apr (15.97\%), only to decrease in May (12.92\%), Jun (10.58\%), Jul (13.62\%), Aug (13.36\%), Sept (10.79\%), Oct (4.47\%), and lowest was in Nov $(0.72 \%)$. The data suggested that the peaks of the recruitment were in April (15.97\%) and Juli (13.62\%) (Figure 7). This process was correlated with the fact that the fish did not spawn at once but rather partially spawned. Spawning affected their recruitment process in the sea as it was correlated with their catchable age upon entering the area.

The natural mortality (M) was below the fishing mortality (F), indicating that kawakawa was intensively exploited in this sea $(\mathrm{M}=1.16$ per year, $\mathrm{F}$ $=2.23$ per year) (Figure 8 ). The high fishing mortality (F) indicated high fishing efforts on the resource. Such high fishing efforts led to high exploitation. The exploitation rate of the fish was $E=0.66$, indicating that the exploitation of this fish already exceeded the optimum exploitation, i.e. $\mathrm{E}=0.5$ (Gulland 1971). This means, kawakawa in this area were already overfished, and, therefore, the current fishing efforts should be reduced by $32 \%$. 


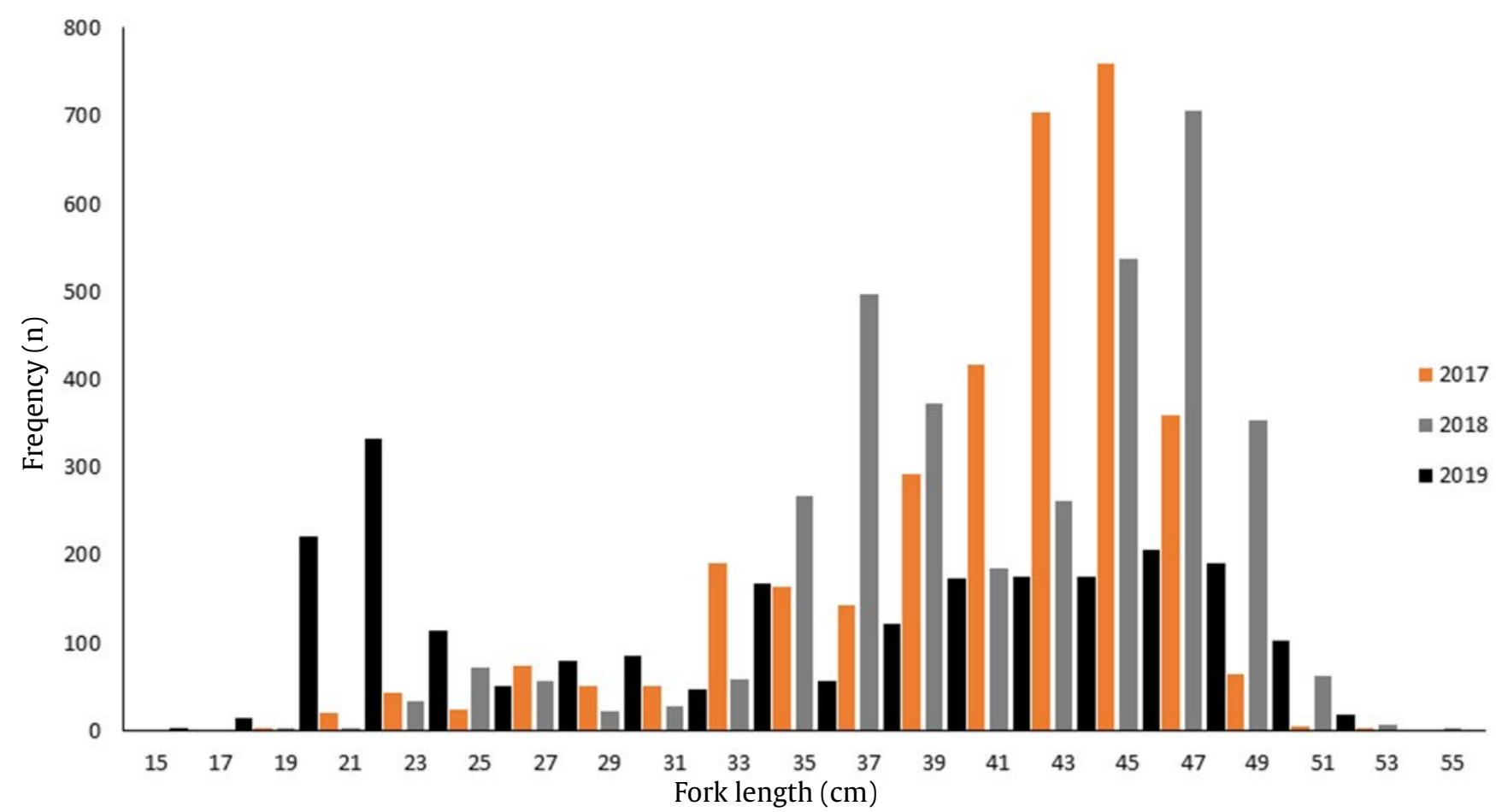

Figure 3. The size structure of kawakawa (Euthynnus affinis) in Java Sea, 2017-2019

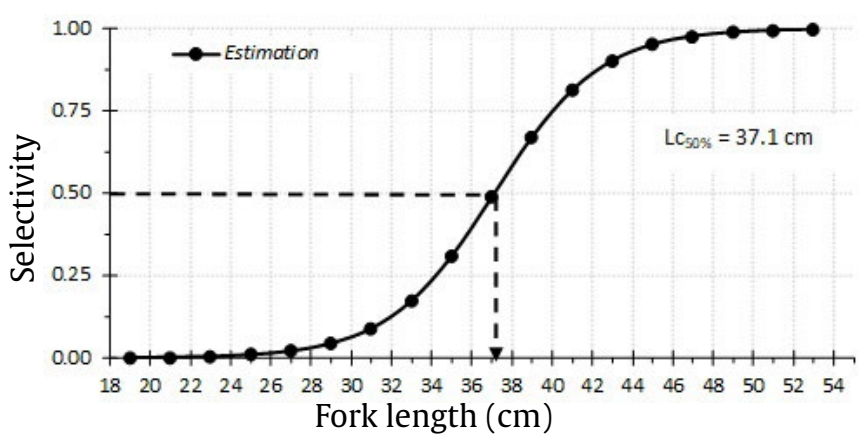

A

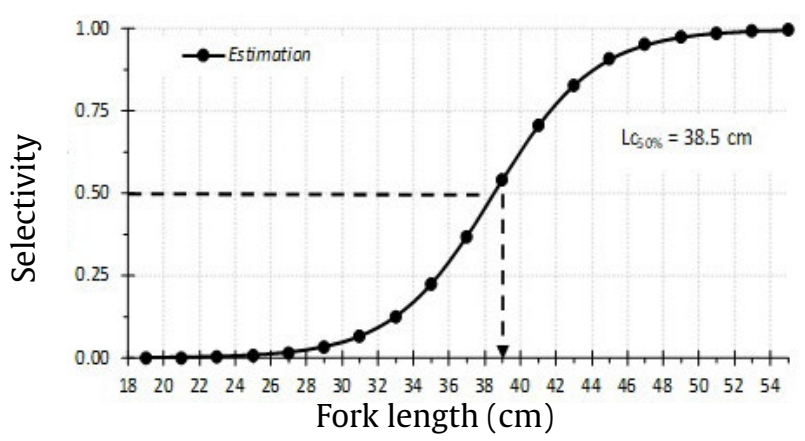

B

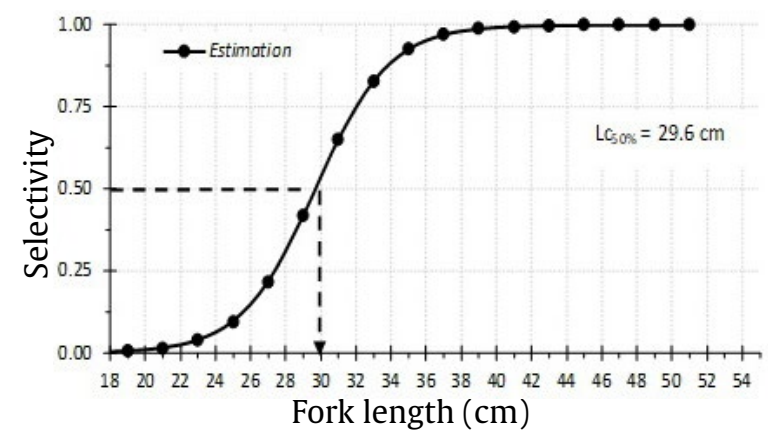

C

Figure 4. The size at first capture (Lc) of kawakawa (Euthynnus affinis) in Java Sea in (A) 2017, (B) 2018, and (C) 2019 


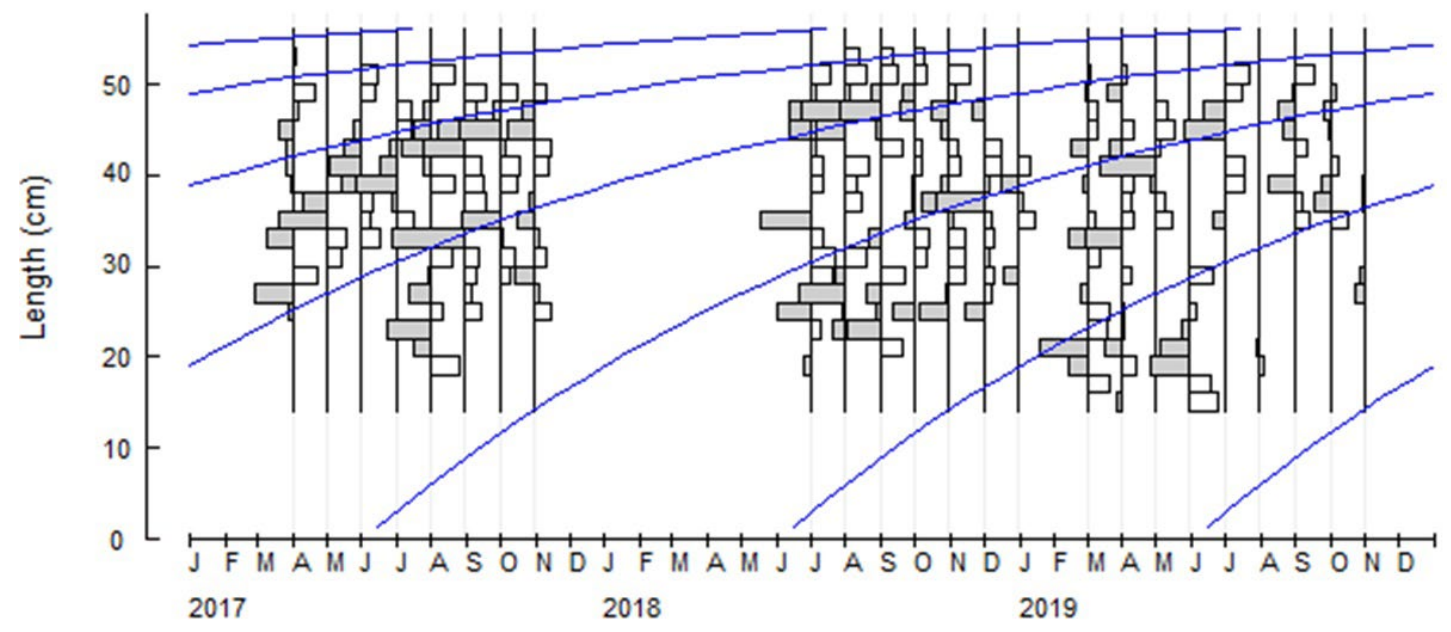

Figure 5 . Von bertalanffy growth rate of kawakawa (Euthynnus affinis) in Java Sea

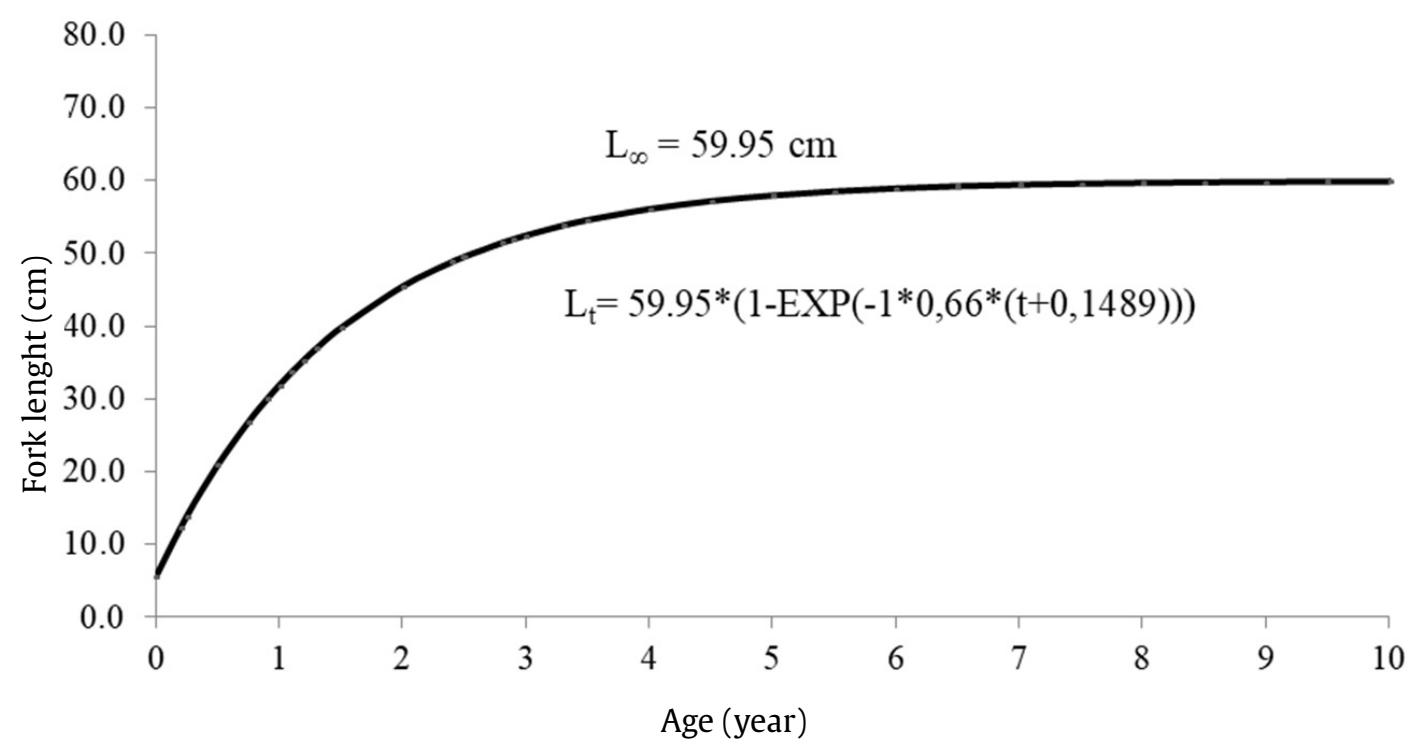

Figure 6. The age and length relation of kawakawa (Euthynnus affinis) in Java Sea

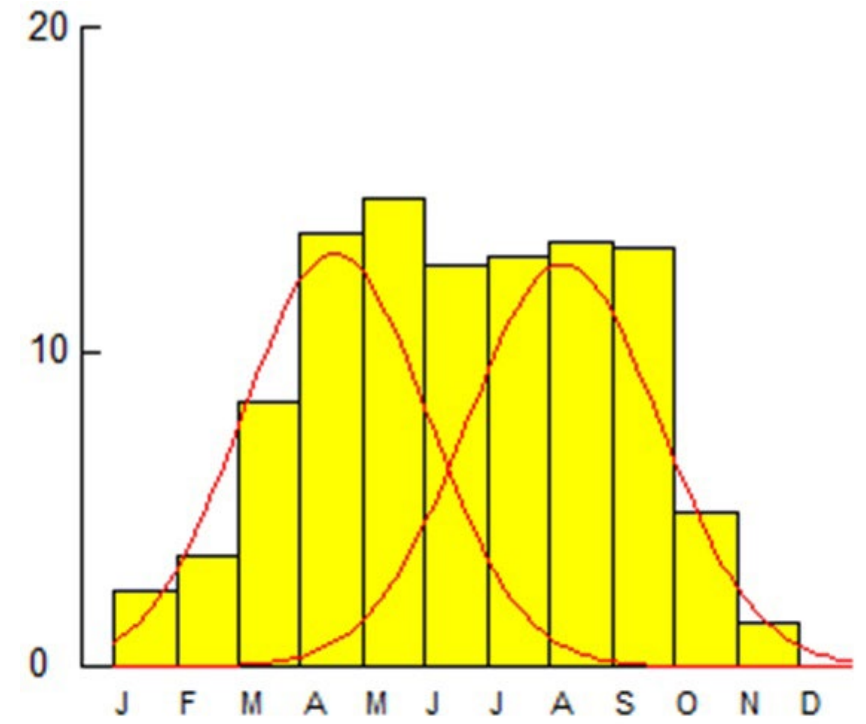

Figure 7. The recruitment pattern of kawakawa (Euthynnus affinis) in Java Sea

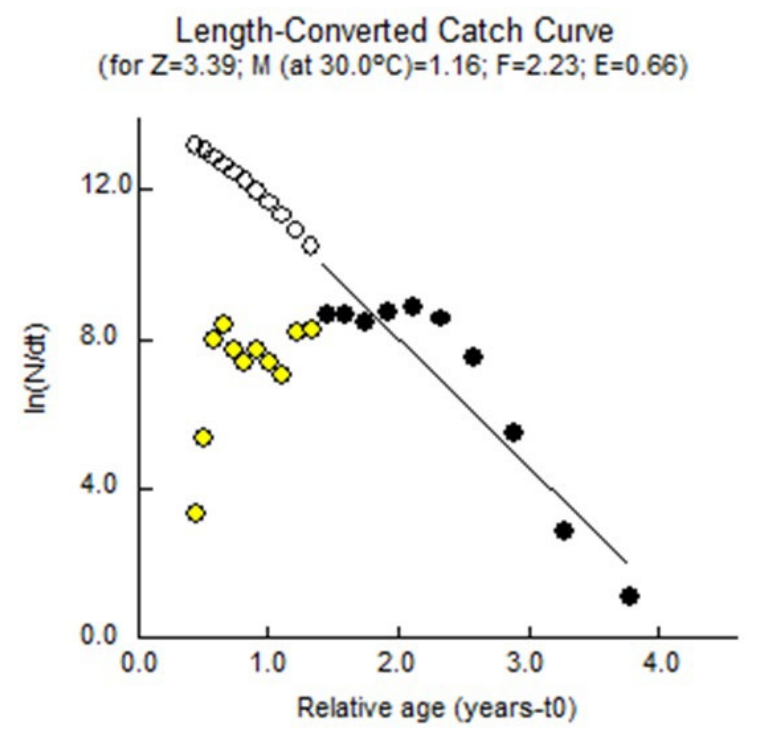

Figure 8. Length-converted catch linear curve of kawakawa (Euthynnus affinis) in Java Sea 


\section{Discussion}

The fishing grounds with the highest catch, as shown by Figure 2 (a, b, and c), were the coastal areas in Indramayu, Tegal, Pekalongan, until Semarang. In 2017, 2018, and 2019, in general, the fishing grounds of purse seines and gillnets in Pekalongan showed no significant shift, and only in 2019 did the fishing grounds shift closer to the coast. Such fishing grounds' locations were in line with kawakawa's natures, i.e. neritic and coastal water-loving fish. In addition, (Simbolon 2009) stated that coastal areas are considered the locations with the highest potential as mackerel tuna fishing grounds. (Widodo et al. 2014) and (Ahmed et al. 2015) also stated that kawakawa is epipelagic in nature, lives in coastal areas, prefers temperature of $18-29^{\circ} \mathrm{C}$ and forms school. In general, coasts also provide sufficient foods for organisms, making numerous fish gather (Mujib et al. 2013). Their schooling habit as well as their habitats make them frequently caught along with other fish such as skipjack tuna, indian mackerel, short mackerel, yellowstripe scads, rainbow sardine, etc. (Wijopriono and Rachmawati P 2015 and Wagiyo et al. 2017). The temperature in Java Sea was $27-29^{\circ} \mathrm{C}$ (Gaol and Sadhotomo 2007), dominantly at $28^{\circ} \mathrm{C}$ (Shabrina et al. 2017). This was in line with Poisson (2006) in (Rohit et al. 2012) and (Santos et al. 2010) who stated that kawakawa prefers temperature of $18-29^{\circ} \mathrm{C}$. In addition, others stated that the fish prefers warm waters with temperature of $28-30^{\circ} \mathrm{C}$ that allows them to survive at the water surface up to $40 \mathrm{~m}$ deep (Feller and Nybakken 1983; Shabrina et al. 2017). Mackerel tunas are sensitive against change in salinity, making their movements in line with the salinity level that can be tolerated by their bodies (Wijopriono and Rachmawati 2015). In addition, Priatna and Natsir (2017) also stated that pelagic fish preferring to dwell in coastal areas have bigger size than those living far away from the coasts.

In general, the kawakawa in this area were 15$55 \mathrm{cmFL}$, bigger than the findings by Chodrijah et al. (2013), i.e. 11.7-55.4 cmFL, and by Hidayat et al. (2019), i.e. 13-55 cmFL, in the same area, and smaller than those landed in Karangsong, Indramayu, i.e. 27-58 cm (Masuswo and Widodo 2016). The size structure in other areas were bigger than in this area, i.e. in Maharastra, India, 26-73 cm (Zafar-Khan 2004), in Kerala, India, 30-64 cm (Pillai et al. 2007), in Iran waters $28-88 \mathrm{~cm}$ (Kaymaram and Darvishi 2012), in India 14-88 cm (Rohit et al. 2012), in West Sumatera 30-60 cm (Jatmiko et al. 2014), in Malacca Strait 16$60 \mathrm{~cm}$ (Wagiyo et al. 2017) and 20-56 cm (Faizal et al. 2017), in Tanjung Luar, West Nusa Tenggara, 24-71 cmFL (Agustina et al. 2018), in Lampulo, Aceh, 17-
$59 \mathrm{~cm}$ (Salmarika et al. 2018), in East Indian Ocean 28-56 cm (Ekawaty and Jatmiko 2018), and in South Lombok 21-77 cm (Wujdi et al. 2020).

The differences in the size of the fish caught are influenced by their food, environment, fishers' fishing grounds, and fishing seasons. Pelagic fish are abundant in the east Java Sea as their distribution is influenced by a biological parameter, i.e. finding food (Atmaja et al. 2003 in Gaol and Sadhotomo 2007). In addition, Realino et al. (2007) stated that fish resource abundance is closely related with food sources. However, in addition to food, the difference in fish size is also influenced by the selectivity of the fishing gears, i.e. the mesh size or the hook size, used to fish (Pane et al. 2020).

The size at first capture (Lc) of the kawakawa in this area ranged from 26.9 to $38.4 \mathrm{~cm}$. The size was smaller than those caught in India, i.e. $41.43 \mathrm{~cm}$ (Rohit et al. 2012). The difference was presumably due to the differences in the measured fish samples, the fishing grounds, the mesh size, and the growth of the caught male and female fish. Based on the results of the study carried out in the same area but the fish were landed in Karangsong Indramayu, the size of the first gonad maturity (Lm) of the kawakawa was $45.8 \mathrm{~cm}$ (male) and $43.2 \mathrm{~cm}$ (female) (Masuswo and Widodo 2016) and $33.7 \mathrm{~cm}$ (Hidayat et al. 2019). On the other hand, in Mangalore waters, India, the $\mathrm{Lm}$ was $43 \mathrm{~cm}$ (female) and $44 \mathrm{~cm}$ (male) (Muthiah 1985), in Kerala, India $43 \mathrm{~cm}$ (Pillai et al. 2007), in India $37.7 \mathrm{~cm}$ (Rohit et al. 2012), in Sunda Strait waters $40.7-40.8 \mathrm{~cm}$ (female) and $43.8-44 \mathrm{~cm}$ (male) (Ardelia et al. 2016), in Malacca Strait $43 \mathrm{~cm}$ (Faizal et al. 2017) and $48.4 \mathrm{~cm}$ (Ekawaty and Jatmiko 2018). In addition, according to IOTC (2017), the size of the gonad maturity of this fish was $38-50 \mathrm{~cm}$.

In general, some of the kawakawa caught and landed in Pekalongan presumably already reached their gonad maturity stage, even though some had not yet. This finding should be taken into account to make sure that the caught fish are bigger than $38 \mathrm{~cm}$. The size can be considered the minimum size of fish with mature gonad that can contribute to increase the number of fish individuals in waters. Based on the analysis, (Hidayat et al. 2019) stated that there was an acceleration in the fish gonad maturation due to the fishing pressure in Java Sea, but at the same time this indicated that the population is starting to be disrupted. In general, fish gonad maturity is influenced by species, age, size, and adaptation to the environment (Lagler et al. 1977). Efforts are imperative to allow fish to reproduce and eventually make the population balance of the kawakawa in this area steady. 
The growth rate of the kawakawa was relatively slow with $\mathrm{K} 0.66$ per year and asymptotic length $(\mathrm{L} \infty)$ of $59.95 \mathrm{cmFL}$. There are various factors leading to the differences in the growth rate $(\mathrm{K})$ and asymptotic length $\left(\mathrm{L}^{\infty}\right)$ of the same fish species from different areas, such as the measured samples, sex, food availability, and water fertility. See Table 1 for the growth rate and the asymptotic length of kawakawa from various areas.

The analysis on the growth rate $(\mathrm{K})$ and the asymptotic length (FLo) indicated that kawakawa in Java Sea reach their asymptotic length when they were 7.5 years old. They are short-lived and (IOTC 2017) stated that their maximum age is 9 years. At first capture, the size of the fish was Lc $=36.9 \mathrm{~cm}$ (in 2017), $\mathrm{Lc}=38.4 \mathrm{~cm}$ (in 2018) at around 1 year old, and $\mathrm{Lc}=26.9 \mathrm{~cm}$ (in 2019) even before they reached 1 year old. Upon reaching 1 year old, the size of the fish in Java Sea were mostly smaller than the same fish in other areas. At 1 year old, the fish in Maharastra waters, India, reached $44.6 \mathrm{~cm}$ in size (Zafar-Khan 2004), in Iran $49 \mathrm{cmFL}$ (Kaymaram and Darvishi 2012), in India $42.7 \mathrm{~cm}$ (Rohit et al. 2012), and in South Lombok, West Nusa Tenggara, $47.6 \mathrm{~cm}$ (Wujdi et al. 2020). The difference in the achieved fish size (length infinity) was due to difference race (genes), food availability, and the contributing environmental condition that affected the rate of the species individual growth.

The amount of food available in their lives accelerate their growth rate, and vice versa. Kawakawa is a typical piscivore, i.e. carnivores with fish as their main diet (Chiou and Lee 2004), particularly pelagic fish (Griffiths et al. 2009). However, according to Carpenter and Niem (2001), mackerel tuna's diet consists of fish, squids, and crustaceans. In addition,

Table 1 . The growth rate and the asymptotic length of kawakawa from other areas

\begin{tabular}{|c|c|c|c|}
\hline Location & $\begin{array}{l}\text { Growth } \\
\text { rate }(\mathrm{K})\end{array}$ & $\begin{array}{l}\text { Asymptotic } \\
\text { length } \\
(\mathrm{cmFL})\end{array}$ & Reference \\
\hline Maharastra, India & 0.79 & 81.7 & $\begin{array}{l}\text { (Zafar-Khan } \\
\text { 2004) }\end{array}$ \\
\hline $\begin{array}{l}\text { Persian Gulf and } \\
\text { Sea of Oman }\end{array}$ & 0.51 & 87.66 & $\begin{array}{l}\text { (Motlagh et } \\
\text { al. 2010) }\end{array}$ \\
\hline $\begin{array}{l}\text { Persian Gulf and } \\
\text { Sea of Oman }\end{array}$ & 0.67 & 95.06 & $\begin{array}{l}\text { (Kaymaram } \\
\text { and } \\
\text { Darvishi } \\
\text { 2012) }\end{array}$ \\
\hline $\begin{array}{l}\text { West of Sumatera } \\
\text { Island, Indian } \\
\text { Ocean }\end{array}$ & 0.63 & 65.53 & $\begin{array}{l}\text { (Jatmiko et al. } \\
\text { 2014) }\end{array}$ \\
\hline Malacca Strait & 0.96 & 64.25 & $\begin{array}{l}\text { (Wagiyo et al. } \\
\text { 2017) }\end{array}$ \\
\hline Malacca Strait & 0.7 & 58.853 & $\begin{array}{l}\text { (Faizal et al. } \\
\text { 2017) }\end{array}$ \\
\hline
\end{tabular}

according to Rohit et al. (2012), their foods are $77 \%$ various types of fish, $14 \%$ crustaceans, and $9 \%$ mollusks, while according to (Widodo et al. 2014) they eat all types of fish as well as Clupea, squids, crustaceans, and zooplanktons. et al. (2019) stated that kawakawa eats Decapterus spp. (mackerel scads), Rastrelliger spp. (mackerel), Leiognathus sp. (ponyfish), and Cypselurus spp. (flyingfish).

Recruitment is a process of adding individuals into waters that are the targets of fishing activities and related to the fish reproduction (Pane et al. 2020). According to Noegroho and Chodrijah (2015), recruitment is influenced by the number of mature female fish that are ready to spawn, mortality during spawning, and the number of fish that reach the stock size. The fish recruitment was related to the entry of kawakawa into the waters, and it occurred all year long, indicating that they are partial spawner. This is in line with Amri et al. (2018) and Ardelia et al. (2016) who stated that kawakawa spawns more than once a year (partial spawner). The recruitment process in April and July was presumably due to the spawning season that occurred from June to August in the sea (Hidayat et al. 2017). A number of studies in other waters also suggested that spawning occurred in June and October (Rohit et al. 2012), August to October (Ahmed et al. 2015), and March and November (Wagiyo et al. 2017). In addition, a prediction indicating that the recruitment of one of the family, i.e. frigate tuna (Auxis thazard), occurs all yar long was also stated by (Ghosh et al. 2012). The estimation of the peak spawning season and the recruitment are the bases for determining policies on fishing season to disallow fishers from capturing fish in recruitment as well as ready-to-spawn fish.

Kawakawa experiences natural and fishing mortalities. Fish natural mortality can be affected by the environment of their habitat, such as temperature, salinity, and predator. Fish natural mortality due to water temperature directly affects fish dietary habit (Griffiths et al. 2009). The exploitation rate of kawakawa indicated that the optimum level of the species had been exceeded ( $\mathrm{E}>0.5$ ). The exploitation rate that already exceeded $32 \%$ indicated that it is imperative to reduce fishing activities. The fishing grounds in Figure 2 above revealed that several areas had a high level of fishing intensity as indicated by their kawakawa's high fishing mortality (F). such a high exploitation rate of kawakawa was presumably because the resource was exploited using a number of different fishing gears, i.e. purse seine, mini purse seine, and gillnet. The fishing activities for kawakawa in Java Sea occurred all year long and had no particular fishing season nor regulations on close season. Considering that kawakawa is a neritic tuna 
species that lives in neritic waters, and based on the fishing grounds they are in overfished areas, it is imperative to regulate the fishing activities to keep the exploitation of the fish under control.

The type of purse seine based and used to capture kawakawa in Pekalongan is large pelagic mini purse seine (Hufiadi and Siti Mardlijah 2019) pursuing free schooling during fishing activities rather than aided with fish aggregating device (FAD). Large pelagic mini purse seine was often locally called PSPB (Purse Seine Pelagis Besar or Large Pelagic Purse Seine) with fishing grounds in Pekalongan waters and its surrounding area. It was different from the large purse seine used to fish until the Makassar Strait and the other areas of Java sea. The PSPB was more of an active fishing gear during its operation, in contrast to gillnet that was relatively more passive. To avoid overlapping between the PSPB and the gillnet $<30$ GT based in Pekalongan, it is necessary to regulate the fishing grounds of both fishing gears. Therefore, further investigation is required to have a clearer understanding on the distribution of the fishing grounds of both fishing gears, spatially as well as temporally.

Population balance can be maintained when fishing efforts are controlled (Pane et al. 2019). This control is imperative to maintain the kawakawa's population balance. However, the control must take into account that this fish is pelagic and migrates. Therefore, coordination must be in place among all relevant stakeholders, including fishermen, fisheries entrepreneurs, fisheries managing actors, and researchers, to maintain the sustainability of kawakawa stock.

The management options that can be taken are among others controlling the permits for the number of mini purse seine/gillnet fishing boats, reducing fishing efforts, regulating mesh size, recommending more selective fishing gears, considering options for closing fishing season, and regulating fishing grounds. Wherever possible, the fishing grounds must be situated outside the spawning grounds to allow the fish to reproduce. It is also crucial to supervise and monitor fishing activities starting from the preparation to go on a trip to the actual fishing activity to ensure the proper implementation of the regulations.

\section{Acknowledgements}

This article is a part of a Study on the Fisheries Biological Characteristics, Resource Habitats, and Fish Resource Production Potential in FMA 712 in Fiscal Year 2017, 2018, and 2019 by the Research
Institute for Marine Fisheries, Cibinong, Bogor, Indonesia. Researchers are thankful to Drs. Suwarso, M.Si and Achmad Zamroni, S.Si, M.Si as the persons in charge for the studies in FMA WPP 712 in 2017, 2018, and 2019, as well as the enumerator for kawakawa resource and Pekalongan National Fishing Port for their cooperation during data collection. The first and second author is the main contributor, while the rest are the member contributors.

\section{References}

Agustina, M., Jatmiko, I., Sulistyaningsih, R.K., 2018. Pola pertumbuhan dan faktor kondisi tongkol komo, Euthynnus affinis (Cantor, 1849) di perairan tanjung luar nusa tenggara barat. Bawal Widya Riset Perikanan Tangkap 10, 179-185. https://doi.org/10.15578/ bawal.10.3.2018

Ahmed, Q., Yousuf, F., Sarfraz, M., Mohammad Ali, Q. Balkhour, M., Safi, S.Z., Ashraf, M.A., 2015. Euthynnus affinis (little tuna): fishery, bionomics, seasonal elemental variations, health risk assessment and conservational management. Frontiers in Life Science 8, 71-96. https://doi.org/10.1080/21553769.2014.96 1617

Amri, K., Nora, F.A., Ernaningsih, D., Hidayat, T., 2018. Reproduction and spawning season of Kawakawa (Euthynnus affinis) based on monsoon and SST distribution in Indian ocean South off JavaNusa Tenggara. Bawal Widya Riset Perikanan Tangkap. 10, 155-167. https://doi.org/10.15578/ bawal.10.2.2018.155-167

Ardelia, V., Vitner, Y., Boer, M., 2016. Reproduction biology eastern little tuna Euthynnus affinis in the sunda strait. Jurnal Ilmu dan Teknologi Kelautan Tropis. 8, 689-700. https://doi.org/10.29244/jitkt.v8i2.15835

Carpenter, K.E., Niem, V.H., 2001. The living marine resources of the Western Central Pacific. Volume 6. Bony fishes part 4 (Labridae to Latimeriidae), estuarine crocodiles, sea turtles, sea snakes and marine mammals. FAO Species Identification Guide for Fishery Purposes.

Chiou, W.D., Lee, L.K., 2004. Migration of kawakawa Euthynnus affinis in the waters near Taiwan. Fisheries Science. 70, 746-757. https://doi.org/10.1111/j.14442906.2004.00867.X

Chodrijah, U., Hidayat, T., Noegroho, T., 2013. Estimasi parameter populasi ikan tongkol komo (Euthynnus affinis) di Perairan Laut Jawa. Bawal. 5, 167-174.

Ekawaty, R., Jatmiko, I., 2018. Biologi reproduksi ikan tongkol komo, Euthynnus affinis (Cantor, 1849) di Samudra Hindia Bagian Timur. Jurnal Ikhtiologi Indonesia, 18, 199-208. https://doi.org/10.32491/jii.v18i3.313

Faizal, E.M., Jamon, S., Jamaludin, N.A., Basir, S., Fishery, M., Development, R., 2017. Neritic tuna fishery and some biological aspects of kawakawa (Euthynnus affinis) in the Malacca Straits. Available at: https://www. iotc.org/documents/neritic-tuna-fishery-and-somebiological-aspects-kawakawa-euthynnus-affinismalacca. [Date accessed: 10 October 2021]

Feller, R.J., Nybakken, J.W., 1983. Marine biology: an ecological approach. Estuaries. 6, 83-86. https://doi. org/10.2307/1351810

Gaol, J.L., Sadhotomo, B., 2007. Karakteristik dan variabilitas parameter-parameter Oseanografi Laut Jawa hubungannya dengan distribusi hasil tangkapan ikan. Jurnal Penelitian Perikanan Indonesia. 13, 201. https:// doi.org/10.15578/jppi.13.3.2007.201-211 
Gayanilo, Jr., F.C., Sparre, P., Pauly, P., 1996. FAO/ICLARM stock assessment tools (FISAT). User's manual. FAO Computerized Information Series.Fisheries.

Ghosh, S., Sivadas, M., Abdussamad, E.M., Rohit, P., Said Koya, K.P., Joshi, K.K., Chellappan, A., Rathinam, M.M., Prakasan, D., Sebastine, M., 2012. Fishery, population dynamics and stock structure of frigate tuna Auxis thazard (Lacepede, 1800) exploited from Indian waters. Indian Journal of Fisheries. 59, 95-100.

Griffiths, S.P., Kuhnert, P.M., Fry, G.F., Manson, F.J., 2009. Temporal and size-related variation in the diet, consumption rate, and daily ration of mackerel tuna (Euthynnus affinis) in neritic waters of eastern Australia. ICES Journal of Marine Science 66, 720-733. https://doi.org/10.1093/icesjms/fsp065

Gulland, 1971. The fish resources of the ocean, Aquaculture. Fishing News (Books) Ltd, Surrey. https://doi. org/10.1016/0044-8486(72)90050-6

Hidayat, T., Febrianti, E., Restiangsih, Y.H., 2017. Pola dan musim pemijahan ikan tongkol komo (Euthynnus Affinis Cantor, 1850) di Laut Jawa. BAWAL Widya Riset Perikanan Tangkap. 8, 101-108. https://doi. org/10.15578/bawal.8.2.2016.101-108

Hidayat, T., Nugroho, T., Chodrijah, U., 2019. Biologi ikan tongkol komo (Euthynnus affinis) di Laut Jawa. Tropical Fisheries Management Journal. 2, 30-36. https://doi. org/10.29244/jppt.v2i1.25315

Hufiadi, Siti Mardlijah, 2019. Perikanan “Jaring Cakalang di Pekalongan" (Kajian Pemanfaatan dan Pengelolaan), In: Prosiding Seminar Nasional Perikanan Dan Penyuluhan II 2019. Lentera Mina. pp. 319-325.

IOTC, 2017. Kawakawa Report. Available at: https://www. iotc.org/documents/kawakawa. [Date accessed: 10 October 2021]

Jatmiko, I., Kartika, R., Nugroho, D., 2014. Laju pertumbuhan, laju kematian dan eksploitasi ikan tongkol di perairan samudera hindia barat sumatera growth, mortality and exploitation rates of kawakawa, Euthynnus affinis (cantor 1849), in Indian Ocean West Sumatera. BAWAL Widya Riset Perikanan Tangkap 6, 69-76. https://doi. org/10.15578/bawal.6.2.2014.69-76

Kaymaram, F., Darvishi, M., 2012. Growth and mortality parameters of Euthynnus affinis in the northern part of the Persian Gulf and Oman Sea. IOTC. 19-21.

King, M., 2007. Fisheries Biology, Assessment and Management. Blackwell Publishing, Toogoom.

KKP, 2018. Kelautan dan Perikanan Dalam Angka 2018. Pusat Data, Statistik dan Informasi Kementerian Kelautan dan Perikanan.

Lagler, K.F., Bardach, J.E., Miller, R.R., Passino, D.R.M., 1977. Ichthyology, Copeia. John Willey and Sons. Inc. new York-London. https://doi.org/10.2307/1443299

Masuswo, R., Widodo, A.A., 2016. Biological characteristic of Kawakawa (Euthynnus affinis) caught by drifting gillnet in the Java Sea. Bawal Widyariset 8, 57-63. https://doi.org/10.15578/bawal.8.1.2016.57-63

Motlagh, S.A.T., Hashemi, S.A., Kochanian, P., 2010. Population biology and assessment of Kawakawa (Euthynnus affinis) in Coastal Waters of the persian Gulf and Sea of Oman (Hormozgan Province). Iranian Journal of Fisheries Sciences. 9, 315-326. https://doi. org/10.22092/ijfs.2018.114076

Mujib, Z., Boesono, H., Fitri, A.D.P., 2013. Pemetaan sebaran ikan tongkol (Euthynnus sp .) dengan data klorofil- $\alpha$ citra modis pada alat tangkap payang (Danish-seine) di perairan teluk Pelabuhanratu, Sukabumi, Jawa Barat. JFRUMT. 2, 150-160.

Mulyana, R., Haluan, J., Baskoro, M.S., Wisudo, S.H., 2011. Analisis multidimensional untuk pengelolaan perizinan perikanan yang berkelanjutan: studi kasus wpp laut arafura. Jurnal Teknologi Perikanan dan Kelautan. 2, 71-80. https://doi.org/10.24319/jtpk
Muthiah, C., 1985. Maturation and spawning of Euthynnus affinis, Auxis thazard and Auxis rochei in the Mangalore inshore area during 1979-82. Bulletin Central Marine Fisheries Research Institute. 36, 71-85.

Noegroho, T., Chodrijah, U., 2015. Parameter populasi dan pola rekruitmen ikan tongkol lisong (Auxis rochei risso, 1810) di perairan barat sumatera. BAWAL Widya Riset Perikanan Tangkap. 7, 129. https://doi. org/10.15578/bawal.7.3.2015.129-136

Pane, A.R.P., Wagiyo, K., Suman, A., 2019. Aspek biologi dan pemanfaatan ikan tenggiri Papua (Scomberomorus multiradiatus munro, 1964) dengan alat tangkap jaring insang di Perairan Merauke dan sekitarnya. Jurnal Ilmu dan Teknologi Kelautan Tropis. 11, 763-776.

Pane, A.R.P., Nurulludin, N., Widiyastuti, H., Suman, A., 2020. Struktur ukuran dan tingkat pemanfaatan ikan lencam (Lethrinus lentjan lacepede, 1802) perairan arafura di Probolinggo. Jurnal Biologi. 13, 128-138. https://doi.org/10.15408/kauniyah.v13i1.14419

Pauly, D., 1980. On the interrelationships between natural mortality, growth parameters, and mean environmental temperature in 175 fish stocks. ICES Journal of Marine Science. 39, 175-192. https://doi. org/10.1093/icesjms/39.2.175

Pauly, D., David, N., 1981. ELEFAN I, a BASIC program for the objective extraction of growth parameters from length-frequency data. ICLARM contribution 28 , 205-211.

Pillai, N.G.K., Jayaprakash, A.., Ganga, U., Kuriakose, S., Appukuttan, K.., Velayudhan, T.., Mohamed, K.., Maisseri, M.K., Radhakishnan, E.., Nandakumar, G., Vivekanandan, E., Sivakami, S., Chakraborthy, R.D., Menon, N.G., Ramachandran, C., Sarada, P.., Laxmilatha, P., Nair, P.N.R., Sivadas, M., Kumar, M.P.P., Philipose, K.K., Mathew, G.M.., Anil, M.., Edwin, L., 2007. Appraisal of marine fisheries of kerala. Marine Fisheries Information Service. 194, 1-9.

Pratama, R.I., Awaluddin, M,Y., Ishmayana, S., 2011. Komposisi asam lemak ikan tongkol, layur, dan tenggiri dari pameungpeuk, Garut. Jurnal Akuatika. 2, 107-115.

Priatna, A., Natsir, M., 2017. Pola sebaran ikan pada musim barat dan peralihan di perairan utara Jawa Tengah. Jurnal Penelitian Perikanan Indonesia. 14, 67. https:// doi.org/10.15578/jppi.14.1.2008.67-76

Realino, B., Wibawa, T.A., Zahruddin, Napitu, A.M., 2007. Pola Spasial dan Temporal Kesuburan Perairan Permukaan Laut di Indonesia. Balai Riset dan Observasi Kelautan, Badan Riset Kelautan dan Perikanan, Departemen Kelautan dan Perikanan.

Rohit, P., Chellappan, A., Abdusssamad, E.M., Koya, K.P.S., Sivadas, M., Ghosh, S., Margaret, A., Rathinam, M., Kemparaju, S., Dhokia, H.K., Prakasan, D., Beni, N., 2012. Fishery and bionomics of the little tuna. Indian Juornal Fisheries, 59, 33-42.

Salmarika, Taurusman, A.A., Wisudo, S.H., 2018. Status pengelolaan sumber daya ikan tongkol di Perairan Samudera Hindia berbasis pendaratan pukat cincin di pelabuhan perikanan Samudera Lampulo, Aceh: suatu pendekatan ekosistem. Jurnal Penelitian Perikanan Indonesia. 24, 263-272.

Santos, M.D., Lopez, G. V., Barut, N.C., 2010. A pilot study on the genetic variation of eastern little tuna (Euthynnus affinis) in Southeast Asia. Philippine Journal of Science. $139,43-50$.

Shabrina, N.N., Sunarto, Hamdani, H., 2017. Penentuan daerah penangkapan ikan tongkol berdasarkan pendekatan distribusi suhu permukaan laut dan hasil tangkapan ikan di perairan utara Indramayu Jawa Barat. Kelautan, Jurnal Perikanan. 3, 139-145. 
Simbolon, D., 2009. Analisis hasil tangkapan dan suhu permukaan laut, kaitannya dengan daerah penangkapan ikan tongkol (Auxis thazard) di perairan Binuangen, Banten. Jurnal Ilmiah Satya Negara Indonesia. 2, 41-48.

Sparre, P., Venema, S.C., 1999. Introduction to tropical fish stock assessment-Part 2: Excercises, FAO. Fisheries Technical Paper.

Wagiyo, K., Pane, A.R., Chodrijah, U., 2017. Parameter populasi, aspek biologi dan penangkapan tongkol komo (Euthynnus affinis Cantor, 1849) dI Selat Malaka. Jurnal Penelitian Perikanan Indonesia. 23, 287. https:// doi.org/10.15578/jppi.23.4.2017.287-297

Widodo, A.A., Satria, F., Sadiyah, L., 2014. Status pemanfaatan dan pengelolaan sumberdaya ikan tuna neritik di Samudera Hindia Wpp 572 dan 573. Jurnal Kebijakan Perikanan Indonesia. 6, 23. https://doi.org/10.15578/ jkpi.6.1.2014.23-28
Wijopriono, Rachmawati, P.F., 2015. Perikanan tongkol dan daya dukungnya terhadap penyediaan bahan baku industri pengolahan di Palabuhanratu. J. Lit. Perikan. Ind. 21, 17-24.

Wujdi, A., Hartaty, H., Setyadji, B., 2020. Estimasi parameter populasi dan rasio potensi pemijahan tongkol komo (Euthynnus affinis, Cantor 1849) di perairan Selatan Lombok.Jurnal Penelitian Perikanan Indonesia. 26, 93. https://doi.org/10.15578/jppi.26.2.2020.93-107

Wujdi, A., Suwarso, 2014. Hasil Tangkapan dan Musim Ikan Tongkol di Perairan Prigi, in: Simposium Nasional Pengelolaan Perikanan Tuna Berkelanjutan. pp. 25-30.

Zafar-Khan, M., 2004. Age and growth, mortality and stock assessment of Euthynnus affinis (Cantor) from Maharashtra waters. Indian Journal of Fisheries. 51, 209-213. 